DOI : https://10.24260/khatulistiwa.v10i1.1693

\title{
MANAGING WORKFORCE DIVERSITY IN ORGANIZATION A CASE STUDY ON AETNA HEALTH CARE SERVICE
}

\author{
Md. Rahat Khan \\ Assistant Professor, Department of Business Administration \\ City University, Khagan, Savar Dhaka, Bangladesh \\ Rahatkhan.mrk14@gmail.com \\ Nanik Shobikah \\ Pontianak State Insititute for Islamic Studies, Pontianak, West Kalimantan, Indonesia \\ nanikshobikah2020@gmail.com \\ Mohammad Abdul Kaium \\ University of Wales Trinity Siant David, London, United Kingdom \\ Mdkaium873@gmail.com
}

\section{HIGHLIGHT}

The study has recommended the Aetna to change the traditional recruitment policy and give more concentration on employee retention rate. Technology driven talent management practices should be the time worthy policy of the Aetna. Focusing more on LAMP and MCC frameworks would enhance the effectiveness and efficiency in recruitment, retention, and talent management policies for the Aetna.

\section{ARTICLE HISTORY}

$\begin{array}{lll}\text { Submit } & : & \text { Apr 22, } 2020 \\ \text { Revision } & : & \text { Apr 24, } 2020 \\ \text { Revision } & : & \text { May 5, 2020 } \\ \text { Minor } & & \\ \text { Accepted } & : & \text { May 5, } 2020 \\ \text { Published } & : & \text { May 5, } 2020\end{array}$

Keyword : $\quad$ Workforce Diversity, Health Care Service, Aetna Inc.

Copyright@2020 The Authors. Published by The Institute for Research and Community Service Pontianak State Institute for Islamic Studies This is an Open Access article under of CC BY-NC-ND 4.0 License https://creativecommons.org/licenses/by-nc-nd/4.0
KHATULISTIWA: Journal of Islamic Studies Vol. 10, No. 1. March 2020
D0I: https://10.24260/khatulistiwa.v10i1.1693 Managing Workforce Diversity in Organization: A Case Study on Aetna Health Care Service 


\section{A. INTRODUCTION}

Aetna health care is the US based financial service which is one of the 100 companies listed in Fortune magazine. The company was founded in May 28 ${ }^{\text {th }}, 1853$ from almost 166 years ago by Eliphalet Adams Bulkeley. Company's headquarter is located in Hartford, Connecticut, USA. The company majorly serves as one of the largest health insurance providers across the USA along with Europe, Southeast Asia, China, and Middle East countries (Aetna, 2019). As the company that operating its business entire the world, the company has a huge diversity in HR and the role of people management is crucial for the company's overall performances including financial as well as non-financial perspectives. As the annual report in 2017, the company currently has a total number of 49,828 employees with many various types of employee diversity (AnnualReport.com, 2019) and the company serves more than 800,000 health service consumers (Aetna, 2019). Aetna is an incorporated company. Company's business activities are run and managed by the board of directors. The number of director boards are 3 to 21 board members. As the annual report in 2016, the company has 12 members in directory panel (Aetna Annual Report, 2016).

Aetna Inc. believes in individual diversity. The diversity is the key aspect of Aetna's business operations. The organization has different types of diversity across the organization such as gender, race, geography, experiences, etc. (Aetna, 2019). The core value of the organization is to manage the diversity and create the equal employment opportunity environment by applying heterogeneity of employees' features as homogeneity. The central three words of Aetna's diversity are embraced, empowered, and engaged (EEE) employees in workforce diversity. To support the diversity value of Aetna, the company builds a different Employee Resource Group (ERGs) based on geography, race, religion, gender etc. As the annually report of Aetna in 2010, the company has 15 ERGs. It is the proper evidence from the company how Aetna properly centered its core value (Diversity Annual Report, 2010).

KHATULISTIWA: Journal of Islamic Studies Vol. 10, No. 1. March 2020
D0I: https://10.24260/khatulistiwa.v10i1.1693 Managing Workforce Diversity in Organization: A Case Study on Aetna Health Care Service 
This current case study focuses on the two important human resource management issues such as diversity in workforce recruitment and retention and diversity in talent management of Aetna Inc. to support Raymond Marcos 35 minutes presentation to the Board of Aetna. The study will also assess the recent issue as well as advantage probability of the company's theme 'The Aetna Way' to compare the HR strategies of Aetna Inc., its other potential competitors, and related environmental challenges. Finally, the study will try to provide some recommendations to the policymakers based on the comparative analysis from the findings through proper justifications.

\section{Concept of diversity in workplace}

Diversity can be referred to the existence of verities among the associates of any community (Jackson et al., 1995). This context has a great significance in any organization, because the organization are becoming more diverse across the globe. That diversification can be based on the origin of employees, ethnic groups, age, race, and genders along with different types of employee's individual characteristics (Shaw and Barrett-Power, 1998). So, the workforce diversity comprises with the employees or people who are showing various behavioral patterns, attitudes, values and norms, desires and needs in organization (Morrison, 1992). Hence, managing diversity is an obvious issue for the organization as well as its different types of performances. Diversity management means forming the heterogeneity in workforce to accomplish to its probability in availing an impartial working environment where the employees or the member groups do not have advantages or disadvantages over the other employees or the member groups (Torres and Bruxelles, 1992). The overall activities of diversity management involve with generating and preserving such a working environment that certainly permits all the employees to reach their complete ability and scope in pursuing the organizational goals (Thomas, 1994). Managing diversity highlights on creating certain employment skills, organizational policies, as well as designing practices which can be unearth the best outcomes from each employee.

KHATULISTIWA: Journal of Islamic Studies Vol. 10, No. 1. March 2020
DOI: https://10.24260/khatulistiwa.v10i1.1693 Managing Workforce Diversity in Organization: A Case Study on Aetna Health Care Service 
The diversity management may create such as comprehensible environment with the aims of enhancing the productivity, work effectiveness, and organizational competitive advantage. The fundamental functions of people management such as recruitment and selection (staffing), training and development programs, employee motivation and incentives, performance evaluation etc. can effectively be managed through actual incorporation of diversity management practice (D'Netto and Sohal, 1999). Form literature a link has been found between organizational goals and the people management practice along with workforce diversity. Figure 1 reflects the link as follows,

Figure 1. Link between organizational goals and the people management practice along with workforce diversity

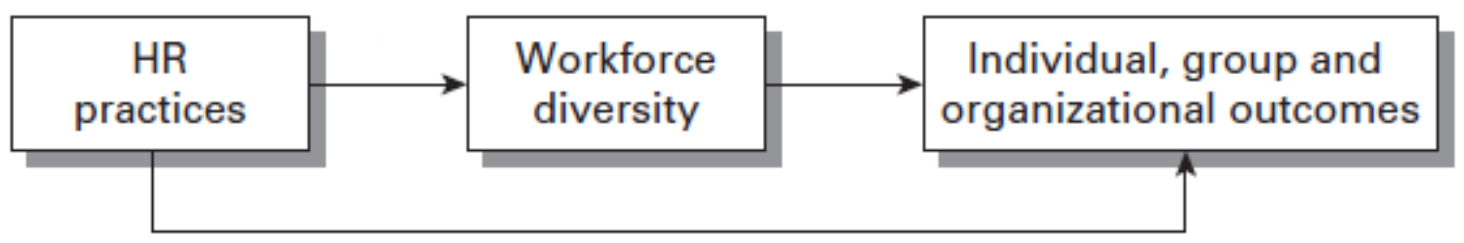

Source. (Kossek, E.E., Lobel, S.A. and Brown, J., 2006)

In promoting the workplace diversity of the organization needs to prepare a strategic people management plan that centers on workplace diversity enchantment strategies and endorse the effectiveness as well as productivity through workforce diversity (Elmuti, 1993). In addition, the organization needs to revisit the overall workplace diversity management practices form upper level to lower level. These workplace diversity approaches support the management and organization for hiring new talents, retaining and managing them more successfully (Denton, 1992).

\section{Diversity in workforce recruitment and retention}

Diversity in employee recruitment along with employee retention is a very significant issue for any organization. In recent time organization tries to catch the best fit of the employees to its respective positions in the organization. Which includes, the

KHATULISTIWA: Journal of Islamic Studies Vol. 10, No. 1. March 2020
D0I: https://10.24260/khatulistiwa.v10i1.1693 Managing Workforce Diversity in Organization: A Case Study on Aetna Health Care Service 
right kinds of people with having suitable experience, knowledge, skills, and other related characteristics are identified in the right kinds of place at right time (Ogunyomi \& Ojikutu, 2014). In furthering that recruiting goal, the diversity in recruiting and retention are the obvious issues (WorkplaceDiversity.com, 2019). For the consequence, organizations have introduced innovative recruitment and selection strategies to obtain the right employees because they can achieve superior performance through the workforce (Baptiste, 2008). Organizations make investment in managing human capital and recruiting people, who possess better skill sets and competencies to deal with the changing paradigms of management (Singh, \& Rao, 2017). In fact, evaluation of human capital as knowledge, experience, skills and appropriate knowledge management (KM) capabilities are prominently required to create long-lasting value and employee commitment (Lahiri \& Kedia, 2009). The company should focus on diverse background of employees through employee resourcing (WorkplaceDiversity.com, 2019). Employee resourcing generally refers to such a process through which organizational employees are placed and allotted to accomplish required task. Resourcing employees has two types of strategic necessities such as reducing the costs and maximizing the value of the employees; and attaining the right kinds of behavioral mixture of employees' attitude along with their organizational commitment (HRM Guide, 2019). Employee resourcing is applied by the organization to capture employment undertakings that emphasis on employees and trade with the issues related to the employee turnover as well as absenteeism (Armstrong, 2012). The foremost actions of employee resourcing comprise with manpower planning, recruitment and selection (staffing), performance management, reward and recognition, along with learning, development, and growth. For any types of organizations, the above activities are directed to response in any rapid changing business environments (Ogunyomi \& Ojikutu, 2014). Literature supports that employee resourcing has a vital relationship on organizational performance. Figure 2 shows the linkage between employee resourcing and organizational performance.

KHATULISTIWA: Journal of Islamic Studies Vol. 10, No. 1. March 2020
D0I: https://10.24260/khatulistiwa.v10i1.1693 Managing Workforce Diversity in Organization: A Case Study on Aetna Health Care Service 
Figure 2. Relationship between employee resourcing and organizational performance

Performance

Employee Resourcing

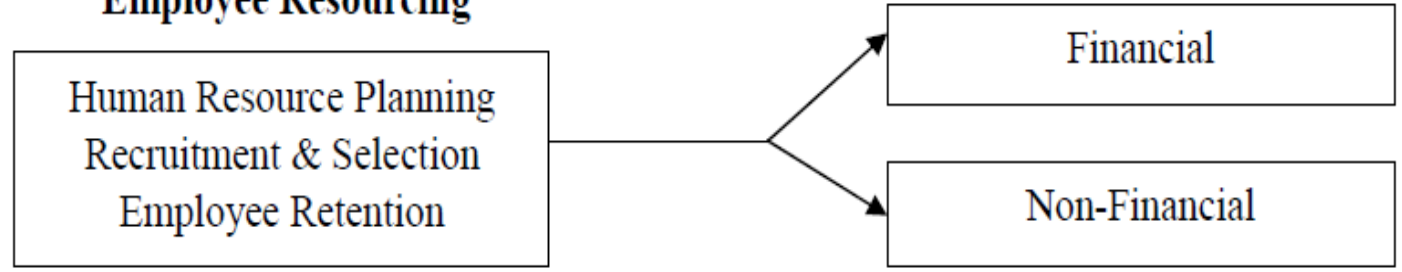

Source. Ogunyomi \& Ojikutu, 2014

The collective collaboration of manpower planning, staffing (recruitment \& selection), employee motivation and retention theorized as the employee resourcing. The employee resourcing effects of performance of the organizations; whether the performances can be determined through the financial performance or the nonfinancial performance or even the both performances. Literatures showed that right kind of recruiting efforts have positive impacts on employee intention to stay as well as on the three components of organizational commitment (Uraon, 2018). Several studies suggest that higher levels of employee engagement reduce turnover intention (Gupta \& Shaheen, 2017). Furthermore, empirical evidence shows that high level of employee engagement is likely to enhance organizational commitment (Gupta, 2017), and job performance (Dalal et al., 2012), and losing any crucial employee costs over a sixty percent $(60 \%)$ of that departed yearly compensation of the losing employee (Cascico, 2000). Therefore, the priority of diversity in recruiting employees and employee retention concept, and the rates of recruiting and retention are very much essential for every company (Albanese, 2019).

\section{Diversity in talent management}

Diversity in talent management (TM) has been increasing progressively; hence there is a continuing debate to define "talent." Meyers et al., (2013) proposed that talent is strength (likely to brilliance); competence (quantifiable capability); compared

KHATULISTIWA: Journal of Islamic Studies Vol. 10, No. 1. March 2020
D0I: https://10.24260/khatulistiwa.v10i1.1693 Managing Workforce Diversity in Organization: A Case Study on Aetna Health Care Service 
with giftedness (inborn distinct ability); high prospective (hidden, but could be improved); or high performance (extraordinary appreciated output). Based on the above statement, TM tactics are characterized as inclusive ("talent" denoting to all staffs) or exclusive ("talent" representing to extraordinary potential or great performers) (Gallardo et al., 2013). Thus, TM can be defined as a procedure to converging on recognizing, judging, developing, and retaining "talent" (Kim et al., 2014). The practice of TM should be aligned with the overall organizational strategies. When the required talent is defined, the succeeding step of TM practice should be categorized as the right talent in the right place for that organization, which includes recruiting and selection of talent (Chaudhuri et al., 2018). Bolander et al., (2017) addresses five strategic TM practices such as "talent recruiting, talent identifying, talent developing, career managing and succession planning, and talent retaining" (p. 1525). Recruiting denotes the actions proposed to hire latent employees from outside of the institution, while talent identifying contains noticing talent or exact competences within. Talent development comprises shaping developmental undertakings for instance proper training or pragmatic learning opportunities such as rotations of job. Career management includes methodical planning that confirms a constant pool of obtainable talent specifically for leadership characters. Retention encompasses activities targeted at dropping the turnover employee and boosting retention of vital skills or employees within (Chaudhuri et al., 2018). The organizations requisite prescribed processes, with numerous stakeholders engaged and solid links between talent and leadership to interpret into TM initiatives into exact institutional value-based behavior. Capabilities and competencies should be assimilated over a process (Thorne \& Pellant, 2007). Some authors recommend the competency model (Kochanski \& Ruse, 1996) as a significant pace towards TM practice in a business (Tyson, 1987) and those capabilities and competencies are not stagnant; thus, organizations need to persistently cultivate new capabilities within the operating environment (Wright et al., 2001). Soft skills, field evaluations, and 360 degrees performance appraisal might be employed in the repositioning of personnel, allowing the business to have an endless talent supply (DeNisi \& Griffin, 2008).

KHATULISTIWA: Journal of Islamic Studies Vol. 10, No. 1. March 2020
DOI: https://10.24260/khatulistiwa.v10i1.1693 Managing Workforce Diversity in Organization: A Case Study on Aetna Health Care Service 
In addition, the diversity in workplace is also a very crucial source for filling the talent gap inside the organization (Mcavoy, 2015).

\section{B. METHOD}

The research is a case analysis of Aetna Inc. based on qualitative approach of research. All the data have been collected from secondary sources such as website of Aetna Inc., annual report of Aetna Inc., deferent types of related articles, blogs, websites etc. The collected data have been analyzed through narrative approach of research. Where all the data have been arranged in a narrative way by utilizing MS Word $(\mathrm{V}, 16)$.

\section{RESULT AND DISCUSSION}

\section{Analyses of the selected two key people management issues}

In this section, the study will critically analyze Aetna Inc.'s overall HR strategies and then select two key people management issues for assessing. The issues are diversity in Aetna's workforce and the employee resourcing techniques of Aetna Inc. After critically analyze the two key people management issues, the study will try to compare the above two people management issues with the company's competitors' strategies. At the end of this section, the study will try to draw some findings based on analysis.

\section{Diversity in recruitment and retention at Aetna}

\section{Aetna's workforce diversity in recruitment and retention policy}

The people management strategy is aligned with the organizational strategy. Company desires an extraordinary quality through cost-effective services in health care and associated solution for its ultimate customers. The consequences of that strategy, the HR is liable to develop an advanced, well diversified, and well performed workforce who can lead the company to become a sustainable one (Cascio, 2009). Aetna Inc. has three separate goals in people management activities. The first goal is to supply a long-term qualified workforce to support the sustainable goal of the organization. The second goal is to identify the core competencies in HR through select, develop, employ, and retain the most talented ones. The third goal is to apply the team

KHATULISTIWA: Journal of Islamic Studies Vol. 10, No. 1. March 2020
D0I: https://10.24260/khatulistiwa.v10i1.1693 Managing Workforce Diversity in Organization: A Case Study on Aetna Health Care Service 
management activities for enhancing the growth of the firm (Cascio, 2009).As per the Aetna Inc.'s website the company place an open door employment opportunities for the mostly talented HR people beyond the origin rather to committed for their career and organizational growth (Aetna, 2019). The organization centers it recruitment and selection activities for the individuals who are from any gender, race, origin, age range, or ethnic groups. The above approaches highlight about the significance of workforce recruitment and retention diversity in Aetna Inc.

- Gender diversity. Aetna believes more on women empowerment in the organization. Currently the organization has $76 \%$ of female employees and $64 \%$ of the female employees are holding the management or supervisory posts. In addition, $32 \%$ of women are holding executive positions in the organization. The Aetna has $4 \%$ of employees who are belong to lesbian, gay, bisexual, transgender. That reflects the diversity in LGBT (Aetna, 2018).

- Race and ethnic group diversity. The race diversity is common in Aetna's workplace. Till now the organization has 32\% of employees are POS (persons of color). Amongst those 19\% of the employee are holing managerial post and 14\% are working as executives (Aetna, 2018). That means the organization try to maintain EEO (equal employment opportunity) practice across the organization.

- Multi-generation workplace diversity. The organization has a great deal of multi-generational diversity in the workplace. As per the Aetna Inc., the organization has $30 \%$ of employees who are in baby boomer generations (Born in year 1946 to 1963). Employees belong to the generation X (Born in year 1964 to 1978) and generation Y (Born in year 1979 to 1994) are consecutively 45\% and 25\%. Employees from both the oldest (traditionalists who are born in 1925 to 1945) and the youngest generation (generation $Z$ who are born in 1995 to 2009 are less than 1\% (Aetna, 2018). The above statistics depict the experience diversity from the employees based on their birth period.

- Geographical diversity. The organization's employees are come from all the 50 states of USA along with some others parts of the world where they are doing their

KHATULISTIWA: Journal of Islamic Studies Vol. 10, No. 1. March 2020
DOI: https://10.24260/khatulistiwa.v10i1.1693 Managing Workforce Diversity in Organization: A Case Study on Aetna Health Care Service 
business. Among the US employees, majority of the employees have come from Connecticut, Arizona, and Pennsylvania based (Aetna, 2018).

- Work-life balance diversity. Aetna's diversity in work-life balance is a very crucial issue. The company has introduced a work-life flexibility related consultancy service program by the experts at $24 / 7$ basis for the employee mental health. This consultancy program centered some key services for the employees as follows.

Table-1. 24/7 work-life flexibility services by Aetna Inc.

\begin{tabular}{|c|c|}
\hline Disability Care & $\begin{array}{l}\text { Disability care serves the disable member from } \\
\text { the employee's family to provide a career on } \\
\text { their request. }\end{array}$ \\
\hline Child Care & $\begin{array}{l}\text { Service includes child caring assistance for the } \\
\text { female employees. }\end{array}$ \\
\hline Parenting & $\begin{array}{l}\text { Consultants assist the new mother providing } \\
\text { suggestions. }\end{array}$ \\
\hline Pet Care & Pet animals caring service for the employees. \\
\hline Elder Care & $\begin{array}{l}\text { Like the child care, elder care serves the } \\
\text { employees' parents caring }\end{array}$ \\
\hline $\begin{array}{l}\text { Discounts in } \\
\text { purchasing } \\
\text { established } \\
\text { branded products }\end{array}$ & $\begin{array}{l}\text { The Aetna employees are availing discount } \\
\text { opportunities for branded product purchasing } \\
\text { such as, travel tickets, clothing, electronics etc. }\end{array}$ \\
\hline $\begin{array}{l}\text { Educational } \\
\text { assistance }\end{array}$ & $\begin{array}{l}\text { The service includes study loan for furthering } \\
\text { the higher study with a minimal amount of } \\
\text { interest for the employees. }\end{array}$ \\
\hline
\end{tabular}

Source. (Aetna, 2019)

As per the statistics the Aetna has $49 \%$ of telework employees and $34 \%$ of managers who are also engaging in teleworking (Aetna, 2018). 
- Tenure diversity. The Aetna has the diversity in year of services by the employees. Recently the organization has $14 \%$ of employees who are working here for more than 20 years. Alongside, $38 \%$ of the employees are working at Aetna for less than 5 years. $2.4 \%$ of the employees are considers as veteran for the company (Aetna, 2018).

Aetna Inc. has a great opportunity of the employees to become the member of that company beyond any barrier regarding age, race, color, ethnicity etc. the company offers almost 100 types of jobs for the employees to develop their career.

\section{Suppliers' diversity at Aetna Inc.}

Aetna Inc. considers diversity at their heart (Diversity Annual Report, 2010). Aetna Inc. allows better services and products for its customers through the diversity in suppliers. The company invites women, minor groups, LGBT, disable people, veteran, along with SMEs (small management enterprises) operated ventures to run their business under the Aetna's suppliers' diversity scheme or program (Aetna, 2019). That diversity program assists the concept of multicultural markets (Gilmore, 2009) through providing the value to its customers. The aforementioned supplier groups can register through online registration and the registration with Aetna's database in free of cost and very easy process. After completing the registration, the registered suppliers can easily contact with the answerable persons of Aetna and can share information and can build future relationship with Aetna as a supplier (Aetna, 2019). The company also engaged with the non-profit agencies, professionals, chamber of commerce, along with local civic leaders. Through these attachments the company achieves a deep thoughtfulness regarding health care facilities and requirements of those particular communities. The company has Second-Tier Subcontracting Program to generate furthermore business prospects. The program permits habitually to the suppliers who are underutilized to work over its major suppliers to offer services and products (Diversity Annual Report, 2010).

KHATULISTIWA: Journal of Islamic Studies Vol. 10, No. 1. March 2020
D0I: https://10.24260/khatulistiwa.v10i1.1693 Managing Workforce Diversity in Organization: A Case Study on Aetna Health Care Service 


\section{Advantages and benefits of diversity}

Diversity of Aetna Inc. can be considered as its competitive advantage in people management strategy (Diversity Annual Report, 2010). Based on the above analysis the study can short out four crucial diversity practices of Aetna Inc. Those diversity practices are found as workforce diversity, workplace diversity, suppliers' diversity, and community and professional alliances' diversity. As the Aetna believes diversity has increased the value of the company (Aetna, 2019). This section closely assesses the advantages of those diversity practices.

\section{a) Benefits of workforce and workplace diversity}

Workforce diversity has some key benefits for any organization and the Aetna Inc. has no difference in this regard. The following benefits have been observed for Aetna in case of workforce and workplace diversity.

- Boosting innovation and creativity for quality services. Diversity in workforce and workplace can increase in innovation in business process. In case of Aetna, the company starts with life insurance service from the beginning of their business in 1861 but till now the company offers group insurance, large case pensions, along with all kinds of health insurances including pharmacy, dental plans, Medicare plans, medical plans etc. (Aetna, 2019; Annual Report, 2016). Diversity in workforce assists the Aetna for more innovation in its business. For instance, Aetna Inc. has 15 numbers of resource groups (Diversity Annual Report, 2010). Among those one of the group Asia Net (Asian American ERG) has innovated a language translation services from English to other languages for better understanding in diversity. That innovation supports all the Aetna's suppliers, employees, customers and other related parties from various language origins to sharing and understanding messages among them effectively (Dundon and Wilkinson, 2012).

- Superior productivity and increase profits. Aetna workforce and workplace diversity have benefits to its superior productivity in business. Aetna operating its business in different parts of the world and the financial growth has been increased in last few years. The company believes the diversity is one of the ways of its superior productivity (Aetnabetterhealth.com, 2018). From the annual report of 2016 the

KHATULISTIWA: Journal of Islamic Studies Vol. 10, No. 1. March 2020
DOI: https://10.24260/khatulistiwa.v10i1.1693 Managing Workforce Diversity in Organization: A Case Study on Aetna Health Care Service 
company has in total $\$ 63$ billion of revenues which is 5\% more than the previous year and the earning per share has also been increased to 7\% from the last year as well (Annual Report 2016). The above statistics support the increase in productivity in case of Aetna's workforce diversity.

- Enhance the employee engagement, accountability and commitment. One of the vital aims of the company escalates the strength of its workforce and workplace diversity importantly through identifying and rewarding the employees for attaining the company's business goals (Aetna.com, 2018). Till now the company has almost 47,000 employees and under the 15 ERGs the company has almost 14,000 employees and all are engaged, accountable and committed to their works (Diversity Annual Report, 2010). Besides the above issues the Aetna has more key benefits on case of workforce and workplace diversity those are as follows;

- Rapid response to its customers and meet the demand for varied customer groups

- Able to make better decision and problem solving in the complex situation

- Build a strong brand reputation for the company as well.

\section{b) Benefits of suppliers' diversity}

Aetna's diversity in suppliers shows the mutual benefits between suppliers along with the company. If any organization which is registered or certified by Aetna's requirements and satisfactorily be evaluated and reviewed by Aetna's suppliers' diversity teams can be the suppliers of Aetna. Through the supplier diversity program the company able to enjoy the marketplace diversity, create a competitive position in the market and make strategic plan for price and services, efficiently be able to collect more information from the customers and improve the quality of existing products, and supports the company to become market leader as well as achieve better profitable growth rate for the company \& shareholders (Aetna, 2019).

c) Benefits of community and professional alliance

Aetna is also focusing on the health services and wellbeing of its community people. The company rely on healthy communities can make a healthier world.

KHATULISTIWA: Journal of Islamic Studies Vol. 10, No. 1. March 2020
D0I: https://10.24260/khatulistiwa.v10i1.1693 Managing Workforce Diversity in Organization: A Case Study on Aetna Health Care Service 
From 2003 the employees of Aetna are spending their 400,000 working hours for developing the community building and supporting activities. The major efforts from Aetna to unite communities through different activities such as, sponsoring to Race to Cure events run by Susan G. Komen's foundation, sponsoring Marathon by Marine Corps in Washington D.C., sponsoring American heart foundation program for women named "Go Red for Women", supporting the LGBT communities accompanied by more community supporting activities (Aetna, 2019) for strengthening the branding of the company (Aetna Settlement Moves Forward, 2013). Through those community services, Aetna can gain more market shares by developing strategies and understanding the specific needs from the specific community. Aetna has successfully understood the demands of varied communities by working by making partnership under the company's community diversity programs.

\section{Comparison of diversity activities in recruitment and retention strategies with the competitors and other top performing companies}

Aetna Inc.'s top competitors are considered as Cigna, UNITEDHEALTH group, Anthem, Humana, WellCare, Centene Corporation, Molina healthcare, High Mark, Capital Blue etc. (Owler, 2019). Aetna has some distinct features in its recruitment and retention techniques from its competitors as well as other world class companies. This section will compare the recruitment and retention activities of Aetna form the top performing companies.

A. Comparison of recruitment policy. Aetna recruitment and selection processes are containing some easy steps to the applicants. As the company is focusing more in diversity so the company takes full support from the IT based recruitment policy. The steps of recruitment and selection process are sharing below,

KHATULISTIWA: Journal of Islamic Studies Vol. 10, No. 1. March 2020
D0I: https://10.24260/khatulistiwa.v10i1.1693 Managing Workforce Diversity in Organization: A Case Study on Aetna Health Care Service 


\begin{tabular}{|l}
\hline Step 1. Job opening from the company and search in online \\
\hline Step 2. Based on criteria fulfilling the application in online and sharing resume. \\
Step 3. After successfully submitting the resume the HR department with \\
review the resume and will offer a phone interview to the applicant. \\
Step 4. A phone interview will take place to collect the further information from \\
applicants. \\
Step 5. Upon finding satisfactory in phone interview the company will offer the \\
applicant for personal interview. \\
Step 6. Finally, after successfully overcome the in-person interview the \\
company will go for reference checking and make a job offer (if the reference \\
checking finds satisfactory).
\end{tabular}

Source. (Aetna, 2019)

Nonetheless, the company emphasizes more on diversity. So, the value of diversity has a huge influential role in Aetna's recruitment policy. In compare to that recruitment policy the following Table 2. will show the comparison in recruitment policies among the competitors and top performing companies.

Table 2. Comparison in recruitment policies

\begin{tabular}{|c|c|}
\hline Company name & Recruitment policy \\
\hline Aetna Inc. & $\begin{array}{l}\text { - } \quad \text { Diversity driven recruitment policy. } \\
\text { - Starts with online base application. } \\
\text { - } \quad \text { Ends with job offering after reference checking } \\
\text { Source: Aetna website }\end{array}$ \\
\hline \multicolumn{2}{|r|}{ Top competitors' recruitment policy } \\
\hline $\begin{array}{c}\text { Cigna Health Care } \\
\text { (competitors of Aetna) }\end{array}$ & $\begin{array}{l}\text { - Customer Relationship based recruitment policy. } \\
\text { - Starts with searching job opening and resume } \\
\text { submission in online. } \\
\text { - Conduct video interview for selecting probable } \\
\text { candidate } \\
\quad \text { Source: Cigna website }\end{array}$ \\
\hline
\end{tabular}

DOI: https://10.24260/khatulistiwa.v10i1.1693 Managing Workforce Diversity in Organization: A Case Study on Aetna Health Care Service 


\begin{tabular}{|c|c|}
\hline $\begin{array}{l}\text { United Health Group } \\
\text { (competitors of Aetna) }\end{array}$ & $\begin{array}{l}\text { - Institutional and personal integrity driven } \\
\text { recruitment policy. } \\
\text { - Online base application system with best fit of the } \\
\text { vacant post. } \\
\text { - Application, then review, assessment, interview, and } \\
\text { final selection then on boarding. } \\
\text { Source: United Health Group }\end{array}$ \\
\hline $\begin{array}{c}\text { Anthem Inc. } \\
\text { (competitors of Aetna) }\end{array}$ & $\begin{array}{l}\text { - Innovation and community driven recruitment } \\
\text { policy. } \\
\text { - Recruitment policy includes both the phone } \\
\text { interview and face to face interview with } 2 \text { managers. } \\
\text { Source: Anthem Inc. }\end{array}$ \\
\hline $\begin{array}{c}\text { Humana Inc. } \\
\text { (competitors of Aetna) }\end{array}$ & $\begin{array}{l}\text { - Cost driven recruitment policy including employee } \\
\text { commitment theme. } \\
\text { - Online application and resume submission. Generally, } \\
\text { it takes } 15 \text { minutes to complete. } \\
\text { - Background checking is must, upon satisfactory the } \\
\text { get offered to the job. } \\
\text { Source: Humana Inc. }\end{array}$ \\
\hline \multicolumn{2}{|c|}{ World's few top performing company's recruitment policy } \\
\hline $\begin{array}{c}\text { Apple Inc. } \\
\text { (Top performing } \\
\text { company) }\end{array}$ & $\begin{array}{l}\text { - Innovation driven recruitment policy } \\
\text { - On average three to four round (group, phone, face to } \\
\text { face) interviews. } \\
\text { Generally, it takes } 2 \text { to } 4 \text { months' time for the whole } \\
\text { recruitment and selection process. } \\
\text { Source: Apple Inc. }\end{array}$ \\
\hline $\begin{array}{l}\text { Microsoft Inc. } \\
\text { (Top performing } \\
\text { company) }\end{array}$ & $\begin{array}{l}\text { Employee empowerment driven recruitment } \\
\text { strategy. } \\
\text { - Academic credentials have given a huge priority in } \\
\text { recruitment process. } \\
\text { - Microsoft doesn't follow any fixed format of } \\
\text { recruitment. Strategy may change based on the team } \\
\text { and job nature. } \\
\text { Applicant analytical ability testing along with } \\
\text { problem solving aptitudes are been tested with highly } \\
\text { importance. Generally, } 4 \text { to } 5 \text { rounds of interviews } \\
\text { may be arranged in whole recruiting and selection } \\
\text { process. }\end{array}$ \\
\hline
\end{tabular}

KHATULISTIWA: Journal of Islamic Studies Vol. 10, No. 1. March 2020
D0I: https://10.24260/khatulistiwa.v10i1.1693 Managing Workforce Diversity in Organization: A Case Study on Aetna Health Care Service 


\begin{tabular}{c|c}
\hline $\begin{array}{c}\text { Facebook } \\
\text { (Top performing } \\
\text { company) }\end{array}$ & - $\begin{array}{l}\text { Employee's' role driven recruitment strategy. } \\
\text { Focusing best fit and interest of the employees. } \\
\text { Very simple recruitment system starts with sharing } \\
\text { resume, reviewing the resume, pre interview } \\
\text { conversation, phone or video calling interview, face to } \\
\text { face interview, final evaluation and then job offered to } \\
\text { the applicants. } \\
\text { Source: Facebook.com }\end{array}$ \\
\hline $\begin{array}{c}\text { Johnson\& Johnson } \\
\text { (Top performing } \\
\text { company) }\end{array}$ & $\begin{array}{c}\text { - } \begin{array}{l}\text { Diversity and inclusion based on recruitment policy. } \\
\text { Online application system through 'Apply Now'. } \\
\text { After assessing the resume, interviews may be } \\
\text { arranged through phone call, video, or in person } \\
\text { depending on the post and position. }\end{array} \\
\text { Final contact through e-mail and get offered. } \\
\text { Source. https://www.careers.jnj.com/how-we-hire }\end{array}$ \\
\hline $\begin{array}{c}\text { Customer centric recruitment policy. } \\
\text { (Top performing } \\
\text { company) }\end{array}$ & $\begin{array}{l}\text { Very simple recruiting process, starts with } \\
\text { application, review the application, arrange } \\
\text { interview, upon successful prepare an orientation } \\
\text { schedule for the new employee. } \\
\text { Source: https://careers.walmart.com/application-process- }\end{array}$ \\
\hline
\end{tabular}

From Table 2, it can be presumed that each and every company has its own pattern of recruitment policies and strategies. However, all of them are focusing their core values to its personnel selection process whether the company is similar to Aetna Inc. or the other top performing companies.

A. Comparison of retention policies. Aetna Inc. received few awards based on their people management practices. The company awarded 'Champion Award' for creating an EEO environment for the employees to showing honor and proper utilization of the employees who are belong to LGBT community. Besides the award more awards named Workplace excellence award, New York Urban League's

Champions of Diversity award, listed in 2010 Corporate Equality Index etc. (Diversity Annual Report, 2010) are the symbol of how the company valued its employees and they center on retention.

Aetna shares regular benefits to its employees through discounting employees for different products and services, providing resource support for the

KHATULISTIWA: Journal of Islamic Studies Vol. 10, No. 1. March 2020
D0I: https://10.24260/khatulistiwa.v10i1.1693 Managing Workforce Diversity in Organization: A Case Study on Aetna Health Care Service 
employees for better living, and giving financial wellbeing to the employees as well (Benefits Overview, 2019). Two of the employees shows their happiness about the Aetna's employee support strategies through comments.

Employee 1 says, "I was overwhelmed to talk about what was going on financially and now after talking about it, I have a plan for how to be free from credit card debt by using resources provided for credit counseling and planning."

Employee 2 says, "It has changed my life ... a new year's resolution is becoming a way of life! Positive reinforcement from staff, and making it easy to stay committed. Love it!

The above analysis of strategies and comments support how the employees are engaged in Aetna and how well the company interested to retain its employees. In table 3 statistics show the average length of engagement in the organization.

Table 3. Average length of tenure among the companies including Aetna Inc.

\begin{tabular}{cc}
\hline Company name & Average length of engagement \\
\hline Aetna Inc. & 4.2 years \\
Anthem Inc. & 4.1 years \\
Cigna Healthcare & 3.6 years \\
Humana Inc. & 2.8 years \\
UnitedHealth Group & 2.7 years \\
Source. https://www.zippia.com/humana-careers-5720/ \\
\hline
\end{tabular}

D0I: https://10.24260/khatulistiwa.v10i1.1693 Managing Workforce Diversity in Organization: A Case Study on Aetna Health Care Service 


\begin{tabular}{cc}
\hline Tesla Inc. & 2.1 Years \\
Facebook & 2.5 Years \\
Microsoft & 4.0 years \\
Uber & 1.8 years \\
Netflix & 3.1 Years \\
Apple & 5 years \\
Johnson \& Johnson & 4.7 years \\
Walmart Inc. & 3.3 years \\
Dell Inc. & 3.8 years \\
- & \\
- $\frac{\text { https://www.businessinsider.com/average-employee-tenure- }}{\text { retention-at-top-tech-companies-2018-4. }}$ \\
$\underline{\text { https://www.payscale.com/data-packages/employee-loyalty/full- }}$ \\
$\underline{\text { list. }}$ \\
\hline
\end{tabular}

Form Table 3, it can easily be believed that, among the healthcare services companies the retention rate of Aetna Inc.'s employees is the highest than the others healthcare firms and the retention rate is also noteworthy in compare to the top performing companies as well.

\section{Diversity in talent management (TM) at Aetna}

Aetna Inc. has its own "Compensation and Talent Management Committee" to support the TM activities. The prime objective of the committee is to reduce the responsibilities of the board of direct or regarding the compensation and talent management related issues of Aetna (Aetna.com, 2019). In case of talent management practices for Aetna, the committee assesses the executive officials' performance both the individual and corporate, based on outcomes of their performance the company designs compensation plans along with different benefit plans for the employees. In addition, the company intends compensation plans which is related to equity-based incentives and review and update the overall strategies regarding company's diversity in talent management issues. 
The approach boosts up moral building of their employees and enhances more engagement towards the company as well. Table 4 shows Aetna's diversity in Talent Management practice at a glance.

Table 4.

Aetna Inc.'s talent management strategies and activities

\section{Compensation and Talent Management Committee}

Step $1 \Rightarrow$ Make strategies and plans for the company's talent management.

Step $2 \Rightarrow$ Assess the performance (personal \& corporate) of executive officials.

\section{$\checkmark$}

Step $3 \Rightarrow$ Offer new compensation and benefits (equity-based incentive) plans for the evaluated officials.

\section{$\checkmark$}

Step $4 \quad \Rightarrow$ Review and update the overall diversity driven talent management strategies.

Source: Aetna.com, 2019

Aetna Inc. believes the strategic importance of talent management practices and that have been considered as one of the key sources of competitive advantages for organizational success in $21^{\text {st }}$ century (Collings \& Mellahi, 2009). So, the Aetna Inc. is investing more purposefully on managing and solving the problem related to the talent management issues (Lyon and Marler, 2011) through embracing numerous strategies to sustain a strong talent pool. In a study by (Lamb \&McKinsey, 2001) revealed that the employable rate of the graduate students from university is only $10 \%$ to $20 \%$. The prospective employees are lack of required training, skills, language and cultural consciousness (Holland, 2008, p. 24). Aetna Inc. appears challenges in case of recruiting and holding the talented experts. In some Indian industrial sectors, the attrition rate is alarming and particularly the rate is observed as $40 \%$ to $45 \%$ in IT (information technology) and business process outsourcing areas (Bhatnagar, 2007).

D0I: https://10.24260/khatulistiwa.v10i1.1693 Managing Workforce Diversity in Organization: A Case Study on Aetna Health Care Service 
Another investigation by UKCES (UK Commission for Employment and Skills) titled "Employer Skills Survey 2015: UK Results" unearthed that, 69\% of the participant organizations has lack of fund and $48 \%$ of participant organizations has the failure to staff due on time restraints (Faruk, 2018) are found as major challenges for managing their talent. In case of Aetna's talent management diversity, the company supports $\$ 30$ million grants for the committee to develop talent management program since the year of 2001(Aetna.com, 2019).

\section{Comparison of talent management strategy with the competitors and other companies}

Most of the companies now believe that, talented employees are the sources of competitive advantage and the strength of the organizational people management strategies. For the consequences, Aetna has a strong talented pool of employees and the company spends a portion of its budget to develop the employees' talent through FDR training, yearly performance evaluation, along with handsome compensation and benefits plans (Aetna, 2019). Like the Aetna Inc. all the related competitors or the top performing companies have their own talent management strategies and activities. In table 5, the analysis reflects the talent management strategies and activities of Aetna's competitors and other top performing companies across the globe.

Table 5. Talent management strategies and activities of Aetna's competitors and other top performing companies.

\begin{tabular}{c|c}
$\begin{array}{c}\text { Company } \\
\text { Name }\end{array}$ & \multicolumn{1}{c}{ Talent Management Strategies } \\
\hline $\begin{array}{c}\text { Cigna } \\
\text { Healthcare } \\
\text { (Aetna's } \\
\text { competitors) }\end{array}$ & - $\begin{array}{l}\text { Changed new talent management strategies from 2018. } \\
\text { Develop a Human Capital Management System through proper } \\
\text { training and continuous learning \& develop opportunities for the } \\
\text { employees. } \\
\text { Company has career management program to assist the } \\
\text { employees through proper career planning. } \\
\text { Source.https://www.cigna.com/about-us/corporate- } \\
\text { responsibility/report/our-people/employee-development }\end{array}$ \\
\hline
\end{tabular}

D0I: https://10.24260/khatulistiwa.v10i1.1693 Managing Workforce Diversity in Organization: A Case Study on Aetna Health Care Service 


\begin{tabular}{|c|c|}
\hline $\begin{array}{l}\text { UnitedHealt } \\
\text { h Group } \\
\text { (competitors } \\
\text { of Aetna) }\end{array}$ & $\begin{array}{l}\text { - Company focuses more on veteran or military for their } \\
\text { employees. This means they focus more on experienced } \\
\text { employees. } \\
\text { - Company supports in theme 'Diversity and Inclusion' and under } \\
\text { the theme concept company build cross generation work teams. } \\
\text { - Web based learning and accessibility for developing and } \\
\text { learning the employees. } \\
\text { Source.https://www.unitedhealthgroup.com/about/diversity/workplace } \\
\underline{\text { html }}\end{array}$ \\
\hline $\begin{array}{l}\text { Anthem Inc. } \\
\text { (competitors } \\
\text { of Aetna) }\end{array}$ & $\begin{array}{l}\text { - Anthem has revised their talent management policy from } 2018 \\
\text { like Cigna Healthcare. } \\
\text { - The average hours of training have been increased in 2018. In } \\
2016 \text { it was } 24.6 \text { hours, in } 2017 \text { it was } 25.5 \text { hours, and } \\
\text { surprisingly in } 2018 \text { it has been set for } 30.7 \text { hours including } \\
2,316,960 \text { hours of total consumption during the training. } \\
\text { - Anthem Learning Network (ALN) supports the employees for } \\
\text { career learning and plan. The network provides 10,000 of } \\
\text { resources with free of cost to the employees. } \\
\text { More programs have been arranged for TM practices, such as } \\
\text { Leadership development program, Executive coaching, and } \\
\text { Performance management. } \\
\text { Source.https://www.anthemcorporateresponsibility.com/talent- } \\
\text { development }\end{array}$ \\
\hline $\begin{array}{r}\text { Huma } \\
\text { (comp } \\
\text { of A }\end{array}$ & $\begin{array}{l}\text { - Company uses a holistic approach to develop the talents. The } \\
\text { approach includes supporting and inspiring employees' } \\
\text { individual goal. } \\
\text { - Company has a 'Work-life balance' strategy for the employees to } \\
\text { develop a good employment culture. } \\
\text { Source. https://www.humana.com/careers }\end{array}$ \\
\hline $\begin{array}{l}\text { Apple Inc. } \\
\text { (Top } \\
\text { performing } \\
\text { company) }\end{array}$ & $\begin{array}{l}\text { - Apple Inc. has strong and dynamic talent management activities } \\
\text { for the employees. The company has career development } \\
\text { library, weekly seminar (One-hour session) for sharing } \\
\text { concurrent business and career information to the employees, } \\
\text { employee evaluation and counseling program. } \\
\text { - The Apple University is another resource to build a talent } \\
\text { development and majority of the details are retained in secret. } \\
\text { Source. http://andresjauregui.com/2017/11/17/talent-development- } \\
\text { apple-vs-huawei/ }\end{array}$ \\
\hline
\end{tabular}




\begin{tabular}{|c|c|}
\hline $\begin{array}{l}\text { Microsoft } \\
\text { Inc. } \\
\text { (Top } \\
\text { performing } \\
\text { company) }\end{array}$ & $\begin{array}{l}\text { Microsoft has multibillion dollars TM opportunities through } \\
\text { digital HR along with Dynamics } 365 \text { business application for } \\
\text { managing talents. } \\
\text { - } \\
\text { Dynamics } 365 \text { apps can care the Microsoft's HR to advance the } \\
\text { through categorize, interviewing, selecting and hiring the } \\
\text { suitable candidates, developing efficient compensation plans, } \\
\text { implementing the time-tracking system for payroll, and } \\
\text { maintaining the workplace health, compliance, and safety. All } \\
\text { the above talent management activities can be done under the } \\
\text { Dynamics } 365 \text { apps. } \\
\text { Source. https://blogs.partner.microsoft.com/mpn-canada/talent- } \\
\text { management-opportunity/ }\end{array}$ \\
\hline $\begin{array}{l}\text { Facebook } \\
\text { (Top } \\
\text { performing } \\
\text { company) }\end{array}$ & $\begin{array}{l}\text { Facebook has some unique ways to develop its talents. One of } \\
\text { the key ways is Acquihiring. By using that approach Facebook } \\
\text { first acquire a small farm ant its employees after all of their } \\
\text { customers and other related issues. The same way Facebook } \\
\text { purchase Instagram. } \\
\text { - Another talent management developing way is Contest-based } \\
\text { recruiting. By this approach Facebook arrange different types } \\
\text { of contests through internet and finally select the best ones from } \\
\text { the contestants. } \\
\text { Source. https://www.inc.com/the-build-network/2-tips-from- } \\
\text { facebooks-talent-management-process.html }\end{array}$ \\
\hline $\begin{array}{l}\text { Tesla Inc. } \\
\text { (Top } \\
\text { performing } \\
\text { company) }\end{array}$ & $\begin{array}{l}\text { - Tesla Inc.'s talent management is centered on employee } \\
\text { engagement policy. } \\
\text { - Tesla has invented its own Tesla360 degree summary. } \\
\text { - Company has an extensive training program related to develop } \\
\text { the skills related to vehicle revolution. The training course } \\
\text { duration is } 12 \text { weeks. } \\
\text { Source. https://www.tesla.com/careers/tesla-start }\end{array}$ \\
\hline $\begin{array}{l}\text { Google Inc. } \\
\text { (Top } \\
\text { performing } \\
\text { company) }\end{array}$ & $\begin{array}{l}\text { - Google Inc. has its own funding to develop their talents. } \\
\text { Company try to recruit the right kind of people, then try to } \\
\text { improve their managerial abilities, providing employees } \\
\text { regular feedback for their development. Empowering } \\
\text { employees to bring them in company decision making } \\
\text { processes, finally continuously assess and update their } \\
\text { retention strategies. } \\
\text { Company applied the MCC framework to develop its talents. } \\
\text { Four areas have been covered under the MCC framework. } \\
\text { Those are role of employees, their pace, amount of workload, } \\
\text { and location or schedule of theirs works. By implementing the } \\
\text { model in Google Inc., the employees are getting more } \\
\text { responsible and enjoying more authorities. } \\
\text { Source. Robinson, } 2014\end{array}$ \\
\hline
\end{tabular}

KHATULISTIWA: Journal of Islamic Studies Vol. 10, No. 1. March 2020
D0I: https://10.24260/khatulistiwa.v10i1.1693 Managing Workforce Diversity in Organization: A Case Study on Aetna Health Care Service 
Based on the above analysis it can be believed that like the Aetna each of the organization has their own patterns of talent management activities. Nonetheless, Aetna Inc. emphasis more on diversity-driven talent management approaches. Aetna offers internships opportunity to the fresh graduates for increasing their work experience, boosting their confidence as well as improving the skills. Near about $80 \%$ of the interns concluded with having a new job just next to the end of their internship program (Aetna, 2019). Company also launched post-college prospects program and targets the fresh college graduates (Aetna, 2018).

\section{Recommendation and justification}

From the above analyses the study now tries to draw some recommendations for the people management department of Aetna Inc. related to how they can improve the situation and how they can merge or renovate some ideas from the people management issues practices from the other competitors or top performing companies across the globe. In this section, the recommendations along with justification are divided into three parts. First one will be recommendation and justification for recruitment strategies and practices, second one will be recommendation and justification for employee retention strategies and practices, and final one will be recommendation and justification for talent management strategies and practices.

\section{Recruitment and retention strategies and policies}

A. It is observed that, the world is changing towards the technology driven strategies however the Aetna Inc. is still the very traditional recruitment and hiring process. Even though the two close competitors (Cigna and Anthem) of the Aetna have changed their recruiting policies (see Table 2). So, the initial recommendation for Aetna's recruiting policy to revisit the tradition recruiting system. The prime reason to revisit the traditional recruitment system is, the system may push in suspicion regarding the stability of employees in the organization. As the company believe in diversity in recruitment but the existing recruiting system cannot be suitable to the value of the Aetna's recruiting policy. By using the traditional

KHATULISTIWA: Journal of Islamic Studies Vol. 10, No. 1. March 2020
DOI: https://10.24260/khatulistiwa.v10i1.1693 Managing Workforce Diversity in Organization: A Case Study on Aetna Health Care Service 
approach company will never be able to attract the best set of the diversified panel of employees. The application of psychometric test for both of the individual and group behaviour cases in recruiting policy will be beneficial for the Aetna. That test is advantageous in two cases; the company can learn the employee's individual attitudes and behaviour towards the job along with the group behaviour within the diversified peer group.

$B$. From the analysis one of the Aetna's competitors named Humana Inc. emphasis more on employees' background test. The background test has some vital importance in recruiting strategies such as that test can minimize risks. The reason is, Aetna focuses on diversity and diversified employees have different origins which may have some intention towards criminal activities or harmful diseases. The company can enforce the background test mandatory and the benefits of the test is minimizing the criminal intension risk, support to avoids liability, confirms workplace health and safety, also provide more competent employees.

C. Another important issue is that, from the prior analysis it is been observed that Aetna believes in diversity and focuses more on external sources of employees. As per the people management knowledge both the internal and external sources having some significances in recruitment policies. So, another recommendation can be made for the company to ensure the equal important opportunities and highlight the online application system for both the internal and external candidates.

$D$. To increase the retention rate of the employees each and every company should focus on employee engagement policies along with paying market rate of salary and benefits, right kind of working culture, more training opportunities etc. In case Aetna, the company is diversified one and having multicultural employees so it is better to create its own culture. Building own organizational culture will support the theme of the company called 'The Aetna Way'. The Aetna's culture will reduce the inferior complexity from the minor groups and enhance more commitment and engagement. Right kinds of employee evaluation or technology-based performance appraisal system will increase the employees' credibility towards their good performance measurement. Finally, performance based rewarding system will also increase the employees' commitment and emotional attachment for Aetna.

KHATULISTIWA: Journal of Islamic Studies Vol. 10, No. 1. March 2020
DOI: https://10.24260/khatulistiwa.v10i1.1693 Managing Workforce Diversity in Organization: A Case Study on Aetna Health Care Service 


\section{Talent management strategies and policies}

Unlike the other competitors and the top performing companies Aetna's talent management approaches are still not up to dated and very casual in nature. So, the following recommendations may strengthen the Aetna's Talent management strategies and policies.

A. Technology based talent management is essential for Aetna. In case of Cigna and Anthem healthcare they changed their TM strategies from 2018 through implementing more training programs and its length. The companies also introduce information system based of training and career management program. The benefits of the approach for Aetna would be, employees will believe a smooth career in Aetna and will be more committed as well as performance oriented.

$B$. The company should properly utilize the 'LAMP' framework for future latent management issues. By applying the LAMP framework Aetna will be benefited as follows,

- Logic: Aetna's logical concentration on future investment, HR practices, and other organizational issues will enhance the overall performances and reduce the unwanted and overstate costs.

- Analytics: Active analytics on the diversity issues and data base decision may make the organization more competitive among the competitors.

- Measure: Effective measurement on organizational performances and diversity management issues may support the aim of Aetna.

- Process: Effectiveness and efficiency in managing talent process for developing human capital in Aetna and future supply of the employees may be strengthen the Aetna's talent management goals.

C. Another important recommendation for Aetna's talent management policy is to implement the 'MCC' framework like the Google Inc.'s talent management policy. The MCC will allow the Aetna for setting the pace of work, then to make learn the 
employees about their role in organization, then able to measure the amount of their workload and can set a desirable rate of workload, finally prepare the location as well as work schedule for the diversified employees. The MCC framework can be very much beneficial for the Aetna's talent management strategies as the above ways.

\section{CONCLUSION}

Nowadays, global organizations are promoting and emphasizing the diversity driven and environmentally friendly strategies. It is proven truth that the people management policies should be align with the organizational overall strategies. From the above analyses and discussions, it can be observed that Aetna Inc. is emphasis and successfully implemented on diversity management practices. Nevertheless, each of the company has some pros and cons in their strategies and in case of Aetna there is no exception of that rules. The study centers Aetna's recruitment and retention policies along with talent management policies. The study has also tried to compare the selected policies with the Aetna's competitors as well as top performing companies across the globe. The study reveals that, Aetna should still to go a long way in compare to the other companies. The company should change the traditional recruitment policy and give more concentration on employees' retention rate. Technology driven talent management practices should be the time worthy policy of the Aetna. Focusing more on LAMP and MCC frameworks would enhance the effectiveness and efficiency in recruitment, retention, and talent management policies for the Aetna. The study will have a great impact on the policymakers who are engaging in HR diversity in an organization. The HR students will also get a clear idea about the real-life workforce diversity case study on Aetna Inc.

KHATULISTIWA: Journal of Islamic Studies Vol. 10, No. 1. March 2020
D0I: https://10.24260/khatulistiwa.v10i1.1693 Managing Workforce Diversity in Organization: A Case Study on Aetna Health Care Service 


\section{BIBLIOGRAPHY}

Aetna Settlement Moves Forward. (2013). Psychiatric News, 38(21), pp.2-2.

Aetna. (2018). Workplace diversity. Retrieved from web, https://www.aetna.com/aboutus/diversity-inclusion/workplace-diversity.html.

Aetna. (2019). About us. Retrieved from, https://www.aetnainternational.com/en/aboutus.html.

Aetna. (2019). Retrieved from web, https://www.aetna.com/individuals-families.html.

$\begin{array}{llll}\text { Aetna.com. (2019). Anc. } & \text { Aetna }\end{array}$

Committee on Compensation and Talent Management Charter. Retrieved from, https://www1.aetna.com/investors-aetna/governance/committee comp org.html.

Aetnabetterhealth.com. (2018). Cultural Competency. [online] Available at: https://www.aetnabetterhealth.com/ny/providers/information/cultural [Accessed 18 Nov. 2019]

AnnualReport.com. (2019). 2016 Annual Report, Retrieved from, http://www.annualreports.com/Company/aetna-inc.

Benefits Overview. (2019). Adventure: 2019 Benefits overview. Retrieved from web, http://www.aetna.com/about-aetna-insurance/document-library/careers/benefitsoverview.pdf.

Bhatnagar, J. (2007). Talent management strategy of employee engagement in Indian ITES employees: key to retention. Employee relations, 29(6), pp.640-663.

Bolander, P., Werr, A. and Asplund, K. (2017). The practice of talent management: a framework and typology. Personnel Review, 46(8), pp.1523-1551.

Cascio, W. (2009). Aetna: Investing in Diversity. Society for Human Resource Management (SHRM).

Chaudhuri, S., Hirudayaraj, M. and Ardichvili, A. (2018). Borrow or Grow: An Overview of Talent Development/Management Practices in Indian IT Organizations. Advances in Developing Human Resources, 20(4), pp.460-478.

D0I: https://10.24260/khatulistiwa.v10i1.1693 Managing Workforce Diversity in Organization: A Case Study on Aetna Health Care Service 
Collings, D.G. and Mellahi, K., (2009). Strategic talent management: A review and research agenda. Human resource management review, 19(4), pp.304-313.

D’Netto, B. and Sohal, A.S. (1999). Human resource practices and workforce diversity: an empirical assessment. International Journal of Manpower, 20(8), pp.530-547.

Dalal, R.S., Baysinger, M., Brummel, B.J. and LeBreton, J.M. (2012). The relative importance of employee engagement, other job attitudes, and trait affect as predictors of job performance. Journal of Applied Social Psychology, 42, pp. E295-E325.

Diversity Annual Report. (2010). 2010 Diversity Annual Report. Retrieved from, http://www.aetna.com/diversityannualreport/aetna.html.

Diversity Annual Report. (2010). Embraced. Empowered. Engaged. Retrieved from, http://www.aetna.com/diversityannualreport/mobile/pdf/2010 DiversityAR.pdf.

Dundon, T. and Wilkinson, A. (2012). Case studies in global management. Australia: Tilde Publishing and Distribution.

Gallardo-Gallardo, E., Nijs, S., Gallo, P., and Dries, N. (2013). The who, when, where, and how of talent management: A bibliometric analysis. University of Barcelona Working Paper.

Gupta, M. (2017). Corporate social responsibility, employee-company identification, and organizational commitment: Mediation by employee engagement. Current Psychology, 36(1), pp.101-109.

Gupta, M. and Shaheen, M. (2017). Impact of work engagement on turnover intention: moderation by psychological capital in India. Business: Theory and Practice, 18, p.136.

Holland, K. (2008). Working all corners in a global talent hunt. The New York Times, 24. HRMGuide. (2019). Employee Resourcing, Retrieved from, http://www.hrmguide.co.uk/glossary/employee-resourcing.htm.

Jackson, S.E., May, K.E. and Whitney, K. (1995). Understanding the dynamics of diversity in decision-making teams. Team effectiveness and decision making in organizations, 204, p.261.

Kim, Y., Williams, R., Rothwell, W.J. and Penaloza, P. (2014). A strategic model for technical talent management: A model based on a qualitative case study. Performance Improvement Quarterly, 26(4), pp.93-121.

KHATULISTIWA: Journal of Islamic Studies Vol. 10, No. 1. March 2020
DOI: https://10.24260/khatulistiwa.v10i1.1693 Managing Workforce Diversity in Organization: A Case Study on Aetna Health Care Service 
Kossek, E.E., Lobel, S.A. and Brown, J. (2006). Human resource strategies to manage workforce diversity. Handbook of workplace diversity, pp.53-74.

Lahiri, S. and Kedia, B.L. (2009). The effects of internal resources and partnership quality on firm performance: An examination of Indian BPO providers. Journal of International Management, 15(2), pp.209-224.

Lamb, S. and McKenzie, P. (2001). Patterns of Success and Failure in the Transition from School to Work in Australia. Research Report.

Lyons, B.D. and Marler, J.H. (2011). Got image? Examining organizational image in web recruitment. Journal of managerial psychology, 26(1), pp.58-76.

Mcavoy, K. (2015). Report: 'Diversity' and 'Inclusion' Important for Talent Management. Retrieved from, https://spendmatters.com/2015/11/18/reportdiversity-and-inclusion-important-for-talent-management/.

Ogunyomi, P.O. and Ojikutu, R.K. (2014). Employee resourcing and performance of small and medium enterprises in Lagos State, Nigeria.Journal of Entrepreneurship and Business Innovation, 1(1), pp.16-35.

Owler. (2019). Aetna's Competitors, Revenue, Number of Employees, Funding and Acquisitions. Retrieved from, https://www.owler.com/company/aetna.

Renee Baptiste, N. (2008). Tightening the link between employee wellbeing at work and performance: A new dimension for HRM. Management decision, 46(2), pp.284-309.

Robinson, R. (2014). Talent Management Framework: Human Resources, Role, and Strategies $\begin{array}{lll}\text { at } & \text { Google Inc. } & \text { Retrieved }\end{array}$ https://russiarobinson.wordpress.com/2014/06/23/talent-managementframework-human-resources-role-and-strategies-at-google-inc/.

Shaw, J.B. and Barrett-Power, E. (1998). The effects of diversity on small work group processes and performance. Human Relations, 51(10), pp.1307-1325.

Singh, P.K. and Rao, M.K. (2017). HR practices, learning culture and human capital: a study on Indian business and professional service sector. Global Business Review, 18(3), pp.678-690. 
Uraon, R.S. (2018). Examining the impact of HRD practices on organizational commitment and intention to stay within selected software companies in India. Advances in Developing Human Resources, 20 (1), pp.11-43.

WorkplaceDiversity.com. (2019). Why is Diversity Important in Recruiting and Retention? Retrieved from, https://workplacediversity.com/news/Why-isDiversity-Important-in-Recruiting-and-Retention.

Wright, P.M., Gardner, T.M., Moynihan, L.M., Park, H.J., Gerhart, B. and Delery, J.E. (2001). Measurement error in research on human resources and firm performance: Additional data and suggestions for future research. Personnel Psychology, 54(4), pp.875-901. 


\section{APPENDIXES}

- Appendix 1. Lists of abbreviations

LGBT = Lesbian, Gay, Bisexual, and Transgender

EEO = Equal Employment Opportunity

POS $=$ Point of Service plan

$\mathrm{ERG}=$ Employee Resource Groups

FDR $=$ First Tier, Downstream and Related Entities (FDR)

MCC $=$ Mass Career Customization

- Appendix 2. LAMP framework

The Logic of Employee Health and Wellness

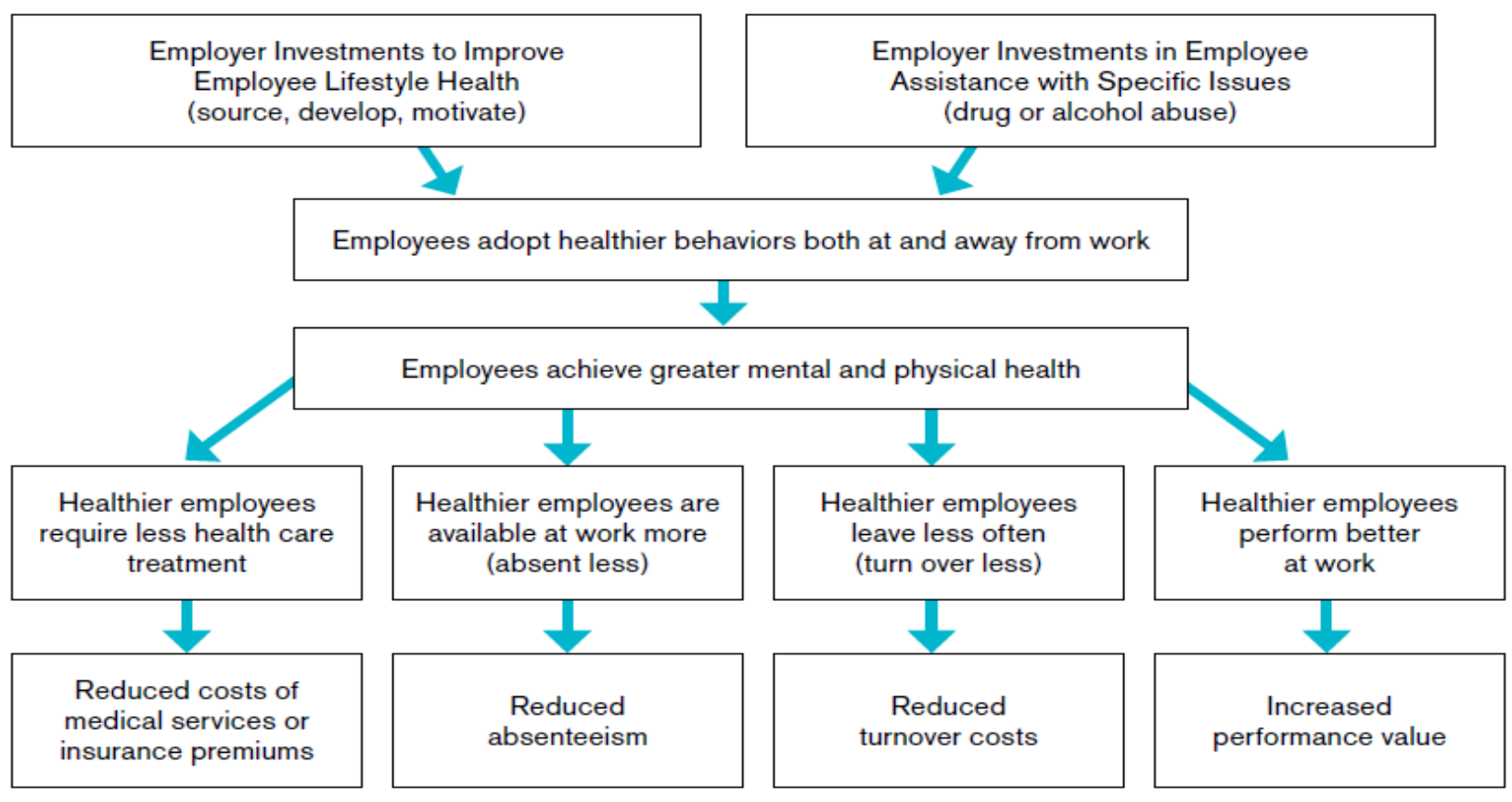

Source. Cascio \& Boudreau, 2008

- Appendix 3. MCC framework

D0I: https://10.24260/khatulistiwa.v10i1.1693 Managing Workforce Diversity in Organization: A Case Study on Aetna Health Care Service 


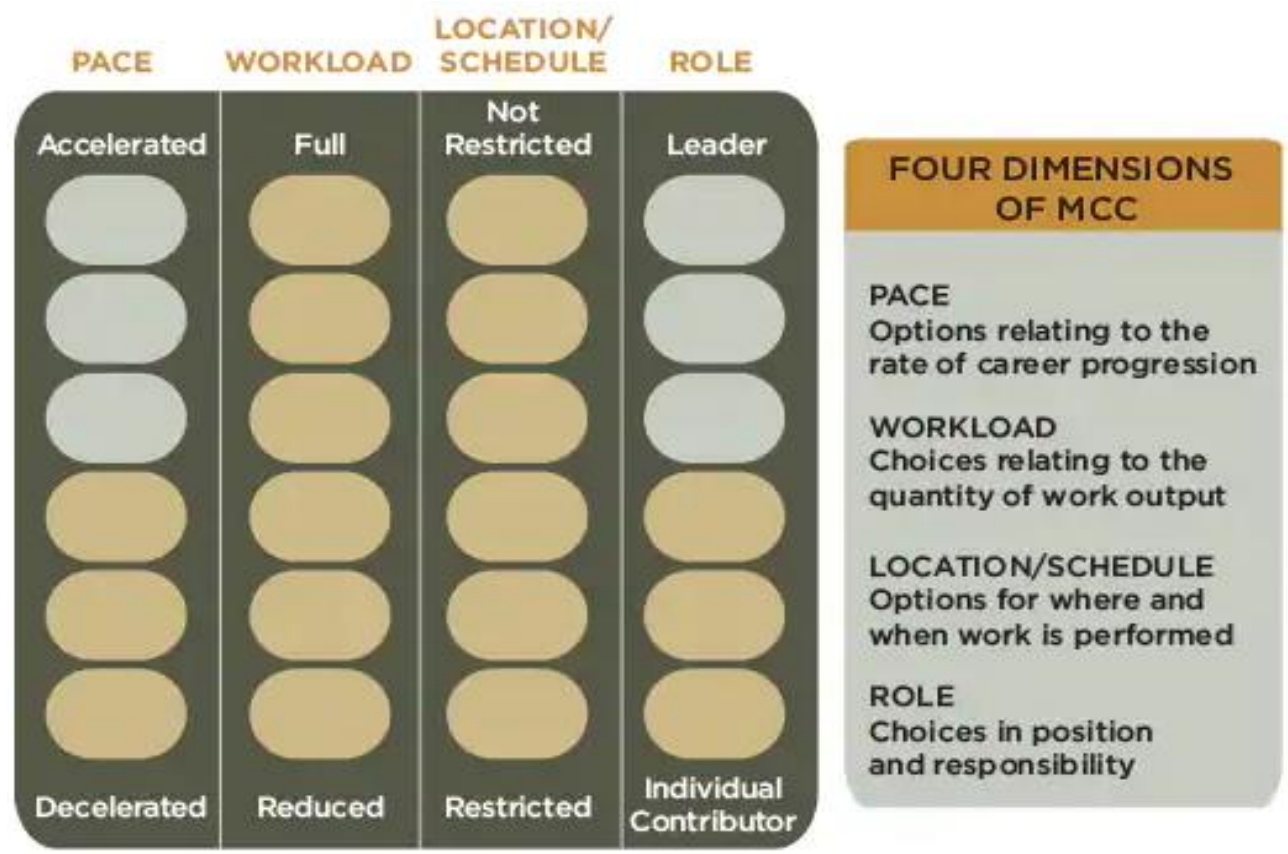

Source. Benko \& Weisberg, 2008

DOI: https://10.24260/khatulistiwa.v10i1.1693 Managing Workforce Diversity in Organization: A Case Study on Aetna Health Care Service 